\title{
Chronology of Weichselian main ice marginal positions in north-eastern Germany
}

\author{
Christopher Lüthgens, Margot Böse
}

Abstract:

\begin{abstract}
The chronology of the Weichselian Pleniglacial in north-eastern Germany was so far mainly based on morphostratigraphy and radiocarbon ages of organic sediments underlying glacigenic deposits. Throughout the last years direct dating approaches, i.e. Optically Stimulated Luminescence (OSL) dating of glacioflucial deposits and surface exposure dating (SED) of erratic boulders, have been applied in a number of studies. We summarise and reassess the results of these studies following a process based interpretation model and propose a new chronology for the main ice marginal positions in north-eastern Germany. The available data give evidence for a twofold last glaciation with the Brandenburg phase representing an ice advance which occurred in late Marine Isotope Stage (MIS) 3 to early MIS 2, and the Pomeranian phase representing an ice advance reaching its maximum extent at $\sim 20 \mathrm{ka}$. The final stabilisation of the land surface after initial deglaciation was highly dependent on active landscape transformation during phases characterised by periglacial conditions. First numerical ages point towards the occurrence of such an activity phase at about $\sim 15 \mathrm{ka}$.
\end{abstract}

[Chronologie weichselzeitlicher Haupteisrandlagen in Nord-Ost-Deutschland]

Kurzfassung:

Bisher basierte die Chronologie des Weichsel-Pleniglazials in Nord-Ost-Deutschland im Wesentlichen auf morphostratigraphischen Befunden und Radiokohlenstoffdatierungen organischer Sedimente aus dem Liegenden glazigener Ablagerungen. Im Laufe der letzen Jahre kamen im Rahmen verschiedener Studien Datierungsmethoden zum Einsatz, mit deren Hilfe es möglich war, die glazigenen Sedimente direkt zu datieren: Optisch Stimulierte Lumineszenz (OSL) von glazifluvialen Sedimenten und Oberflächen-Expositionsdatierungen (surface exposure dating, SED) von erratischen Blöcken. Wir fassen die Ergebnisse dieser Studien zusammen und bewerten sie auf der Grundlage eines prozessbasierten Interpretationsschemas neu, um somit eine neue Chronologie für die weichselzeitlichen Haupteisrandlagen in Nord-Ost-Deutschland vorstellen zu können. Auf der Grundlage der verfügbaren Daten lassen sich zwei Phasen während des letzten Glazials nachweisen, wobei die Brandenburger Phase einen Eisvorstoß im späten Marinen Isotopenstadium (MIS) 3 bis frühen MIS 2 repräsentiert, während die Pommersche Phase einen Eisvorstoß widerspiegelt, der seinen Maximalstand um 20 ka erreichte. Hinsichtlich der endgültigen Stabilisierung der Geländeoberflächen nach der initialen Eisfreiwerdung zeigt sich eine hohe Abhängigkeit von Phasen aktiver Transformation unter periglazialen Bedingungen. Erste Ergebnisse numerischer Datierungen deuten auf eine solche Aktivitätsphase um 15 ka hin.

Keywords: $\quad$ Weichselian glaciation, Optically Stimulated Luminescence, OSL, surface exposure dating, Pomeranian Phase, Frankfurt Phase, Brandenburg Phase, deglaciation

Addresses of authors: M. Böse, C. Lüthgens ${ }^{*}$, Freie Universität Berlin, Department of Earth Sciences, Institute of Geographical Sciences, Physical Geography, Malteserstr. 74-100, 12249 Berlin, Germany. E-Mail: m.boese@fu-berlin.de, c.luethgens@fu-berlin.de, phone: +0049 30 83870400, fax: +004930 83870751; *corresponding author

\section{Introduction}

North-eastern Germany is an area with a long tradition of Quaternary research and was the type area where the glacial theory was established for Northern Germany by the end of the 19th century (summarised in LüTHGENS \& BösE 2010). In contrast to adjacent areas such as the Jutland Peninsula and parts of Mecklenburg-Vorpommern, the ice marginal positions of the Weichselian Glaciation especially in Brandenburg are located well to the north of the maximum extent of previous glaciations (Fig. 1) and well apart from each other (Fig. 2). Hence, this area is particularly suitable for geochronometrical studies, because the assignment of glacial landforms to a specific ice advance is mainly straightforward. However, during the past 130 years the classification of the Weichselian Pleniglacial has mainly been based on morphostratigraphical interpretations. As TERBERGER et al. (2004) pointed out, a reliable chronology of the Weichselian ice decay based on numerical ages is still lacking. Assumed ages of ice marginal positions are either pure estimates or are based on extrapolations of radiocarbon ages from covering or underlying organic sediments. However, during the last years a significant number of studies using different numerical dating techniques have been conducted in north-eastern Germany. The aim of this review is to integrate the individual results of these studies into a coherent model for the Weichselian landscape development and to discuss this model in the context of results from neighbouring countries such as Poland and Denmark.

\section{Morphostratigraphy}

Based on the conceptual model of the glacial series (sequence of typical geomorphological units formed at a stationary ice margin, Penck 1882), first syntheses of the glacial landscape in the peribaltic were provided by, for example, Keilhack (1909). Already in the early 20th century WOLDSTEDT (1925) introduced the pattern of ice marginal 




Fig. 1: Maximum extents (from south to north) of the Elsterian (dark blue), Saalian (blue) and Weichselian (light blue) glaciations in Germany and neighbouring areas (data provided by EHLERS \& GIBBARD 2004). Figure based on a digital elevation model (DEM) derived from hole-filled seamless SRTM data (processed by JARVIS et al. 2006). (Figure modified from LÜTHGENS 2011).

Abb. 1: Maximalausdehnungen (von Süd nach Nord) des Elster-Glazials (dunkelblau), Saale-Glazials (blau) und des Weichsel-Glazials (hellblau) in Deutschland und benachbarten Gebieten (Daten bereitgestellt von EHLERS \& GIBBARD 2004). Abbildung basiert auf einem digitalen Höhenmodell (DHM) abgeleitet aus SRTM Daten (prozessiert von JARVIS et al. 2006).

(Abbildung verändert nach LÜTHGENS 2011).

positions (IMPs) which in general is still valid today. He assigned landforms south of the Glogów-Baruth ice marginal valley (IMV) to the penultimate glaciation and differentiated two phases for the formation of main ice marginal positions during the last glaciation. The "Jütische Phase" consists of the "Brandenburger Phase" and the "Posensche Subphase". The "Pommersche Phase" follows to the north. This morphostratigraphical model already implied a first relative chronology with the southernmost IMP representing the oldest ice advance and a succession of younger IMPs northward towards the Baltic Sea basin (summarised in LüThgens 2011). Apart from these three main IMPs a complex pattern of intermediary systems of recessional terminal moraines has been controversially discussed within scientific discourse (summarised in BösE 1994, 2005, LüthGENS \& Böse 2010). Despite such conflicting interpretations on regional and local scales, the general pattern established by WoLDSTEDT (1925) was later confirmed by LIEDTKE (1975) who differentiates three main IMPs (Fig. 2): the Brandenburg $\left(\mathrm{W}_{1 \mathrm{~B}}\right)$ IMP representing the southernmost extent of the Weichselian glaciation, the Frankfurt IMP

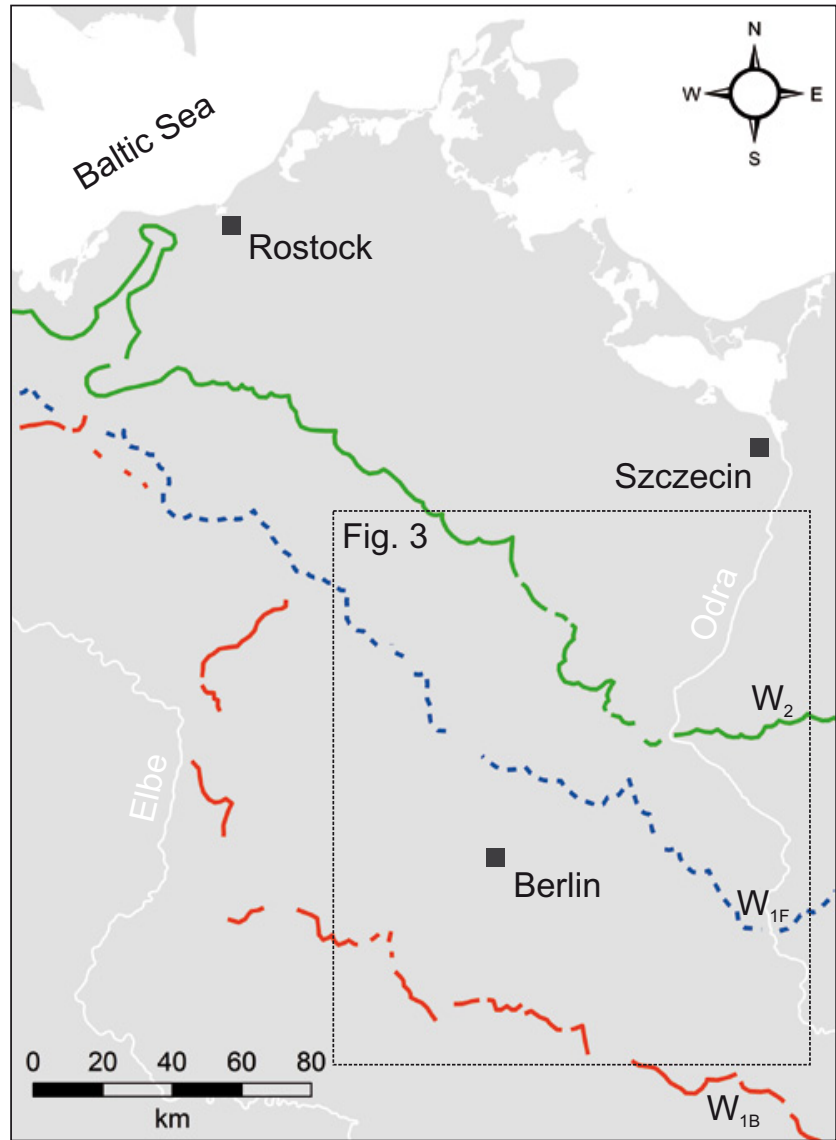

Fig. 2: North-eastern Germany and neighbouring areas of Denmark and Poland, selected cities, and major rivers. Main Weichselian ice marginal positions according to Liedtke (1981): $W_{1 B}-$ Brandenburg phase (red line), $W_{1 F}$ - Frankfurt recessional phase (dashed blue line), $W_{2}$ - Pomeranian phase (green line). (Figure modified from LüTHGENS 2011).

Abb. 2. Nord-Ost-Deutschland und benachbarte Gebiete von Dänemark und Polen, ausgewählte Städte und Haupt-Fließgewässer. Weichselzeitliche Haupteisrandlagen nach Liedtke (1981): $W_{1 B}$ - Brandenburger Phase (rote Linie), $W_{1 F}$ - Frankfurter Rückzugs-Phase (gestrichelte blaue Linie), $W_{2}-$ Pommersche Phase (grüne Linie). (Abbildung verändert nach LÜTHGENS 2011).

$\left(\mathrm{W}_{1 \mathrm{~F}}\right)$ and the Pomeranian IMP $\left(\mathrm{W}_{2}\right)$. Although specific IMVs ("Urstromtäler") have frequently been assigned to these main IMPs (Glogów-Baruth IMV \& Brandenburg IMP, Warszawa-Berlin IMV \& Frankfurt IMP, Toruń-Eberswalde IMV \& Pomeranian IMP), the drainage of meltwater has been shown to be highly complex (e.g., Juschus 2001), with IMVs and meltwater channels still in use after the Scandinavian Ice Sheet (SIS) had retreated north of the Pomeranian IMP. The characteristics of the main IMPs in northeastern Germany will be summarised in the following.

\section{Brandenburg phase $\left(\mathrm{W}_{1 \mathrm{~B}}\right)$ and Frankfurt phase $\left(\mathrm{W}_{1 \mathrm{~F}}\right)$}

Ice marginal features related to the Brandenburg phase and the Frankfurt phase are relatively weakly developed. Due to the rare occurrence of terminal moraines or even push-moraines, both IMPs have mainly been reconstructed along ridges of outwash plains (sandar). Additionally, Saalian push-morainic complexes are known to have been preserved in some places (BösE 2005). This implies an ice advance that adapted to the morphology inherited from the penultimate glaciation (Brose 1995, BrAuer, TempelhofF 
\& Murray 2005, Lüthgens, BöSE \& KrbetscheK 2010). Glaciofluvial deposits and landforms as well as dead ice topography dominate the area between the Brandenburg IMP and the Pomeranian IMP which includes the Frankfurt IMP. Although minor outwash plains and kames occur, they can hardly be assigned to specific IMPs (BöSE 2005). The area is furthermore characterised by intensive glaciofluvial erosion related to the development of a complex system of interconnecting meltwater channels in between the ice marginal valleys. The ice advance to the southernmost Brandenburg IMP has traditionally been ascribed to the Last Glacial Maximum (LGM). The term LGM was originally defined as the global maximum ice volume inferred from the marine isotope record at $\sim 20 \mathrm{ka}$ (BARD 1999), but it is also used as a term describing the maximum ice extent on regional scales. The Brandenburg IMP was supposed to represent the LGM according to both definitions. The Frankfurt IMP is considered to represent a halt in the course of the down-melting of stagnant or even dead ice related to the ice advance to the Brandenburg IMP (Lippstreu 1995, BösE 2005, LitT et al. 2007).

\section{Pomeranian phase $\left(\mathrm{W}_{2}\right)$ and recessional phases}

The most prominent terminal moraines in north-eastern Germany were formed during the Pomeranian phase which is often assumed to represent a strong re-advance of the SIS originating from the Baltic Sea basin (e.g. LIPPSTREU 1995, BöSE 2005). However, other authors (e.g. KLIEwE \& JAHNKE 1972, LIEDTKE 2001) argue that it is more likely that the SIS ice margin remained south of the Baltic Sea basin, because there is no evidence for an interstadial between the $\mathrm{W}_{1 \mathrm{~B} / \mathrm{F}}$ and the $\mathrm{W}_{2}$ phases. Ice marginal features north of the Pomeranian IMP (the most prominent ascribed to the Mecklenburg phase, forming the terminal moraines of the Rosenthal and Velgast IMPs) document the retreat of the SIS further north towards the end of the Weichselian glaciation (BösE 2005).

\section{Radiocarbon based chronology}

With the introduction of radiocarbon dating (LIBBy 1952), the morphostratigraphically based relative chronology was assigned with actual ages (e.g. CEPEK 1965, LIEDTKE 1996, KozArski 1995, Marks 2002, see Table 1). The German Stratigraphic Commision (LitT et al. 2007 and available from the lithostratigraphic lexicon Litholex http://www.bgr.bund. de/litholex which also incorporates more recent data) and LÜTHGENS (2011) recently reviewed the available geochronometrical data (Table 1). However, this radiocarbon based chronology suffers from a number of significant drawbacks. Radiocarbon dating can only be applied to organic deposits. These are usually found in positions under- or overlying minerogenic glacigenic deposits, therefore the obtained ages only provide maximum or minimum ages for the latter. Additional problems may arise whenever the dated organic material is not found to be in situ, but has been reworked by, for example, glacial processes. The ages stated as estimates in Table 1 are mainly based on the model of ice build-up and decay developed by KozARsKi $(1992,1995)$. Based on results from radiocarbon dating from organic deposits underlying the Weichselian glacigenic deposits, he estimated aver-
Tab. 1: ${ }^{14} \mathrm{C}$ based chronology of the main IMPs in north-eastern Germany* Tab. 1: ${ }^{14} \mathrm{C}$ basierte Chronologie der Haupteisrandlagen in Nord-OstDeutschland

\begin{tabular}{|l|l|l|}
\hline IMP & Age** & Method \\
\hline \multirow{3}{*}{ Brandenburg $\left[\mathrm{W}_{1 \mathrm{~B}}\right]$} & $\sim 20$ ka BP & Estimate $^{1}$ \\
\cline { 2 - 3 } & $<24$ cal. ka BP & ${ }^{14} \mathrm{C}^{2}$ \\
\hline \multirow{3}{*}{ Frankfurt $\left[\mathrm{W}_{1 \mathrm{~F}}\right]$} & $\sim 18.8$ ka BP & Estimate $^{3}$ \\
\cline { 2 - 3 } & $<23.8$ cal. ka BP & ${ }^{14} \mathrm{C}^{4}$ \\
\cline { 2 - 3 } & $<32$ cal. ka BP & ${ }^{14} \mathrm{C}^{5}$ \\
\hline \multirow{3}{*}{ Pomeranian $\left[\mathrm{W}_{2}\right]$} & $\sim 16.2$ ka BP & Estimate $^{6}$ \\
\cline { 2 - 3 } & $<17.6$ cal. ka BP & ${ }^{14} \mathrm{C}^{7}$ \\
\hline
\end{tabular}

1 Cepek [1965], LiedtKe [1981], Kozarski [1995]

2 Age of organic sediments underlying glacial sediments of the Brandenburg phase [MARKS 2002].

3 Age extrapolated from underlying ${ }^{14} \mathrm{C}$ ages, assuming an estimated rate of ice build-up and decay KozARSKI [1995].

4 Age of organic sediments underlying glacial sediments of the Poznan [Frankfurt] phase near Konin, Poland [MARks 2002].

5 Age of an organic silt layer ["Mudde vom Segrahner Berg"] underlying glacial sediments of the Frankfurt phase [LüTTIG 2005].

6 Age extrapolated from underlying ${ }^{14} \mathrm{C}$ ages, assuming an estimated rate of ice build-up and decay KoZARSKI [1995].

7 Age of organic sediments [LIEDTKE 1996, MARKS 2002], origin and stratigraphical position unclear from primary sources.

* Summarised from LiTT et al. [2007], no age uncertainties specified.

** Calibration of ${ }^{14} \mathrm{C}$ ages according to STUIVER et al. [1998] by LiTT et. al. [2007].

age rates of ice build-up and decay of the SIS over time and hereby calculated ages for the different IMPs. Given these different uncertainties the validity of the radiocarbon based chronology has to be regarded as being very limited.

\section{Direct dating of glacigenic deposits}

With the advancements of numerical dating techniques two approaches to directly date glacigenic deposits are now available: Optically Stimulated Luminescence (OSL) dating of glaciofluvial sediments and surface exposure dating (SED) of glacigenic boulders using cosmogenic nuclides (most commonly ${ }^{10} \mathrm{Be}$ ).

OSL dating techniques rely on quartz and feldspar that store radiation damage caused by ionising radiation within their crystal lattice as a latent signal (BøTTER-JENSEN et al. 2003) as long as the minerals are sealed from daylight. Once the minerals are exposed to daylight (e.g. during sediment transport) the OSL signal is reset to zero. The latent OSL signal accumulated during deposition can be measured in the laboratory. The intensity of the signal is a measure for the amount of energy stored within the crystal (equivalent dose) (Bøtter-Jensen et al. 2003; Preusser et al., 2008). Once the rate of stored energy per time is known (dose rate), it is possible to calculate the time elapsed since the crystal was last exposed to daylight. Therefore OSL enables the determination of depositional ages of sediments. However, the proglacial depositional environment is characterised by cloudy meltwater, high sedimentation rates and short transport distances. This may cause insufficient exposure of the mineral grains to daylight and 
consequently the incomplete resetting of the OSL signal prior to deposition. Different approaches are available in order to deal with this problem. Most commonly used is the analysis of equivalent dose $\left(D_{e}\right)$ distributions using statistical minimum age models. The $\mathrm{D}_{\mathrm{e}}$ is determined by comparing the natural luminescence signal with that of laboratory irradiated subsamples (aliquots). Nowadays the single aliquot regenerative (SAR) dose protocol (MURRAY \& Wintle 2000, 2003, Wintle \& Murray 2006) is most commonly used in luminescence dating laboratories worldwide. Here all measurement steps necessary for $D_{e}$ determination are conducted using the same aliquot. By measuring several aliquots for a single OSL sample, $\mathrm{D}_{\mathrm{e}}$ datasets are generated which are suitable for statistical analyses such as the aforementioned statistical age models (e.g. Galbraith et al. 1999, Bailey \& Arnold 2006, Fuchs \& OWEn 2008, Thrasher et al. 2009). A second approach in order to deal with incompletely bleached samples is the reduction of the number of grains per measured subsample (aliquot) ideally down to the single grain level as suggested by Duller (2008). The detectable OSL signal from multigrain aliquots is always an averaged signal consisting of OSL signals emitted by individual grains. By measuring single grains, this averaging effect can be avoided and fractions of well bleached and incompletely bleached grains within heterogeneously bleached samples can be separated. If incomplete bleaching sometimes can not be overcome (e.g. if single grain measurements are not possible due to the luminescence properties of mineral grains within a sample) the obtained ages have to be regarded as maximum ages. For further details on the basic principles and latest developments in OSL dating we refer to recently published methodological review papers (LIAN \& Roberts 2006, Preusser et al. 2008, Wintle 2008a/b).

Surface exposure dating is based on the principle that cosmogenic nuclides build up in minerals exposed to cosmic rays at a predictable rate over time. By measuring the nuclide concentration in samples taken from e.g. rock surfaces or boulders, it is possible to determine how long the sampled material has been exposed at the surface (IvyOcHS \& KoBER 2008). Using mass spectrometric techniques, a broad variety of cosmogenic nuclides can be measured (Gosse \& PHILlips 2001). Most commonly used are the radionuclides ${ }^{10} \mathrm{Be},{ }^{14} \mathrm{C},{ }^{26} \mathrm{Al}$, and ${ }^{36} \mathrm{Cl}$. For a comprehensive review of the theoretical background and the application of cosmogenic nuclide methods we refer to Gosse \& PHILlips (2001). A review focussing on the dating of landforms and deposits by means of SED is available from Ivy-OcHs \& KoBER (2008). Within the two studies providing SED ages for north-eastern Germany to be introduced in the following, different calculation scenarios with respect to different scaling methods and/or correction factors for snow cover, vegetation cover and erosion were provided. Additionally, Rinterkecht et al. (2010) recalculated the SED ages of Heine et al. (2009) for samples from the Pomeranian phase. For reasons of comparability we will only provide uncorrected SED ages calculated according to the Lal (1991)/Stone (2000) (Lm) scaling scheme as calculated by RINTERKNECHT et al. (2010). On the one hand the Lm scaling scheme is assumed to be more appropriate for the age range than alternative scaling themes (RINTERKNECHT et al. 2010), on the other hand, the correction factors for snow, vegetation and erosion introduce additional sources of uncertainty as they are estimates. The three ages for boulders associated with the Brandenburg phase from Heine et al. (2009) had to be recalculated accordingly for this review paper using the CRONUS-Earth online ${ }^{10} \mathrm{Be}$ exposure age calculator version 2.2 (http://hess.ess.washington.edu/math) (BALCO et al. 2008). However, it needs to be stressed that all the different calculation scenarios including the new calculations for this review yield ages which agree within error for the individual samples.

It has to be pointed out that OSL and SED date different processes within the development of glacial landscapes. When OSL is applied to glaciofluvial sands of outwash plains, the process of sediment aggradation linked to meltwater discharge from an ice margin is directly dated. SED applied to erratics determines the age of the exposure and final stabilisation of the sampled boulder after the downmelting of stagnant ice, landscape transformation under periglacial conditions, and the melting of buried dead ice (secondary deglaciation sensu EvEREST \& BRADWELL 2003). This is likely to cause a significant time lag between the initial deglaciation (process intended to be dated) and the final stabilisation and exposure of boulders at the landscape surface (process actually dated). Following LüTHGENS \& BöSE (2010) and Lüthgens, Böse \& Preusser (2011), we therefore propose to interpret SED ages as markers for phases of landscape stabilisation with the oldest exposure ages representing minimum ages of the glacigenic formation of terminal moraines at ice marginal positions. This implies a significant time lag between the ages obtained from both dating methods (LüTHGENS 2011). However, LüTHGENS \& BösE (2010) point out that the combination of both methods - given that the ages are interpreted as described above - may allow a more detailed reconstruction of regional deglaciation patterns. In contrast, the calculation of average ages needs to be handled with care because geochronological details and regional differences in landscape development may thereby be obscured (LüTHGENS \& BösE 2010, Lüthgens, Böse \& Preusser 2011).

The application of that interpretation model also offers an explanation for the phenomenon that SED based ages for specific ice marginal positions mostly yield younger ages than expected from previous chronologies (e.g. HeINE et al. 2009, Houmark-Nielsen, Björck \& Wohlfarth 2006, RinterkneCHT et al. 2005, 2006a/b, 2007, 2008, 2010). As described above, radiocarbon chronologies based on ages derived from organic sediments underlying glacigenic sediments can only provide maximum ages for the latter. As a result a minimum SED age must be younger than a respective maximum radiocarbon age.

\section{Results of numerical dating of glacigenic deposits}

According to the morphostratigraphical classification outlined above, we will firstly provide the results from the area ascribed to the Brandenburg $\left(\mathrm{W}_{1 \mathrm{~B}}\right)$ and Frankfurt $\left(\mathrm{W}_{1 \mathrm{~F}}\right)$ phases and secondly those from the area ascribed to the Pomeranian $\left(\mathrm{W}_{2}\right)$ and its recessional phases (in the following see Fig. 3). 


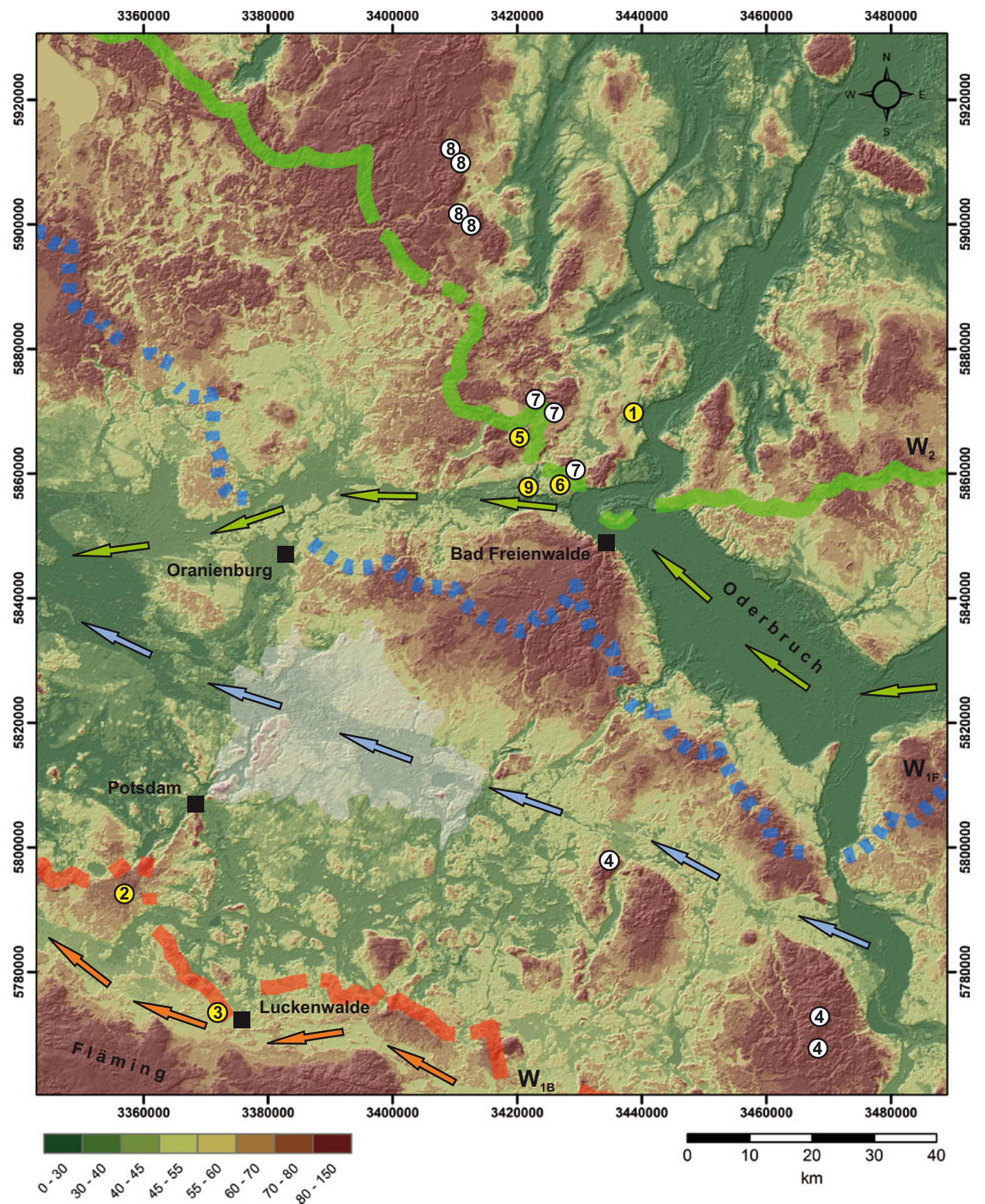

Fig. 3: Weichselian main ice marginal positions in Brandenburg, Berlin (transparent white area), and neighbouring areas according to LIEDTKE (1981): $W_{1 B}-$ Brandenburg phase (orange), $W_{1 F}-$ Frankfurt recessional phase (dashed blue), $W_{2}-$ Pomeranian phase (green). Coloured arrows indicate the general course of main ice marginal valleys: Glogów-Baruth IMV (orange), Warszawa-Berlin IMV (blue), Toruń-Eberswalde IMV (green). Numbers indicate sampling locations of the studies cited in Table 2 with the background colour indicating the dating method applied (OSL - yellow, SED - white). SED locations represent the position of individual boulders sampled for a study, whereas OSL locations indicate sampling sites where multiple samples were taken. Map based on a digital elevation model (DEM) from SRTM data, $90 \mathrm{~m}$ resolution, UTM zone 33N, ETRS 1989.

Abb. 3: Weichselzeitliche Haupteisrandlagen in Brandenburg, Berlin (transparent weiß unterlegter Bereich) und benachbarten Gebieten nach LIEDTKE (1981): $W_{1 B}-$ Brandenburger Phase (orange), $W_{1 F}$ - Frankfurter Rückzugs-Phase (blau), $W_{2}$ - Pommersche Phase (grün). Farbige Pfeile zeigen den generellen Verlauf der Haupt-Urstromtäler an: Glogów-Baruther Urstromtal (orange), Warszawa-Berliner Urstromtal (blau), Toruń-Eberswalder Urstromtal (grün). Zahlen markieren die Beprobungsstandorte der in Tabelle 2 zitierten Studien. Die Hintergrundfarbe gibt Auskunft über die angewendete Datierungsmethode (OSL - gelb, SED - weiß). SED Markierungen entsprechen der individuellen Lage der beprobten Findlinge, OSL Markierungen dagegen entsprechen Beprobungsstandorten, an denen mehrere Proben genommen wurden. Als Kartengrundlage dient ein digitales Höhenmodell (DHM) basierend auf SRTM-Daten mit 90 m Auflösung, UTM-Zone 33N, ETRS 1989. 


\subsection{Brandenburg $\left[W_{1 B}\right]$ and Frankfurt $\left[W_{1 F}\right]$ phases}

For this area dating results from OSL dating of quartz as well as from SED using ${ }^{10} \mathrm{Be}$ have been published: OSL ages obtained from glaciofluvial sediments of outwash plains ascribed to the Brandenburg phase are available for the Beelitz outwash cone (LÜTHGENS et al. 2010, LÜTHGENS 2011) and the Luckenwalde area (LüTHGENS, BöSE \& KRBETSCHEK 2010); SED ages for three erratic boulders from the area in between the Brandenburg and Frankfurt IMPs have been published by Heine et al. (2009).

Lüthgens et al. (2010) dated three samples from glaciofluvial sediments of the Beelitz outwash cone (Fig. 3) using OSL of single aliquots of coarse grained quartz. Significant scatter in the ages determined for the individual samples was observed. The authors explain this scatter in age by the occurrence of incomplete resetting of the OSL signal prior to deposition as detected from the equivalent dose distributions obtained from the OSL measurements. Within the study a single aliquot regenerative dose protocol (SAR) was applied and multigrain aliquots were used. Therefore the authors state the youngest age of $34.1 \pm 3.0 \mathrm{ka}$ obtained from the glaciofluvial sediments as a maximum age. In order to overcome the limitations in age determination caused by the incomplete resetting of the OSL signal, LÜTHGENS (2011) reinvestigated two of the samples from the study of LÜTHGENS et al. (2010) using OSL of single grains of quartz. Due to the fact that only a very small proportion $(\sim 2 \%)$ of the measured quartz grains emitted an analysable OSL signal, the ages calculated for the samples are based on a small statistical basis. LÜTHGENS (2011) argues that because both samples were taken from the same stratigraphical unit (only few decimetres apart from each other) it seems plausible to calculate an average age of $27.7 \pm 4.0 \mathrm{ka}$ for the two samples. This age is not significantly different from the maximum age of $34.1 \pm 3.0 \mathrm{ka}$ derived from the single aliquot measurements of LüTHGENS et al. (2010). In addition to these results from glaciofluvial sediments, LÜTHGENS et al. (2010) also dated three samples from periglacial cover sands on the Beelitz outwash cone which yielded consistent ages of $\sim 15 \mathrm{ka}$.

Near the town of Luckenwalde (Fig. 3) LüthGEns, BöSE o KRBETSCHeK (2010) took 10 samples for coarse grain quartz OSL dating from sandur sediments exposed within two gravel pits. Although different authors had concurrently ascribed the formation of the Luckenwalde end moraine and outwash plain to the Brandenburg phase of the Weichselian glaciation, LÜthgens, Böse \& KRBETscheK (2010) provide evidence for a pre-Weichselian formation of the landform: seven samples from the gravel pit "Weinberge" in the southern part of the outwash plain yielded consistent ages in the range from $\sim 130-150$ ka (MIS 6). Three samples taken from glaciofluvial sediments in the northern part of the landform revealed Weichselian ages. However, due to incomplete resetting of the OSL signal LüTHGENS, Böse \& KRBETSCHEK (2010b) only state a maximum age of $34.4 \pm 7.0 \mathrm{ka}$. Based on the OSL ages, results from fine gravel analyses, and mapping of deformation structures within the glaciofluvial sediments, the authors conclude that the Luckenwalde end moraine and outwash plain was initially formed during the Saalian glaciation, with the Weichselian SIS of the Brandenburg phase reaching the same position, but only reshaping parts of it primarily due to meltwater related processes.

HeINE et al. (2009) sampled three boulders from the area in between the IMPs of the Brandenburg and the Frankfurt phase for SED using cosmogenic ${ }^{10} \mathrm{Be}$ (Fig. 3). The ages range from $18.9 \pm 0.9 \mathrm{ka}$ for the youngest sample to $21.5 \pm 1.1 \mathrm{ka}$ for the oldest sample (ages recalculated as described above). From these ages the authors deduce that the SIS reached its maximum extent during the Weichselian glaciation at 21-20 ka and started to melt back from the Brandenburg IMP at around $19 \mathrm{ka}$. They further argue that these ages indicate an age of the Frankfurt phase of about $18 \mathrm{ka}$.

\subsection{Pomeranian $\left[W_{2}\right]$ and recessional phases}

For the area ascribed to the Pomeranian and its recessional phases OSL ages of glaciofluvial sediments as well as SED ages of glacigenic boulders are available (Fig. 3): LÜTHGENS, Böse \& Preusser (2011) dated glaciofluvial sediments from the Althüttendorf sandur, the Klosterbrücke outwash cone and from within the Eberswalde IMV; HeINE et al. (2009) dated three samples from glacigenic boulders exposed in the Pomeranian terminal moraine; Brauer, Tempelhoff \& Murray (2005) dated glaciofluvial sands exposed in the gravel pit Stolzenhagen; finally, RINTERKNECHT et al. (2010) dated samples from five erratic boulders from the Gerswalde terminal moraine, a recessional phase of the Pomeranian.

LÜTHGENS, BöSE \& Preusser (2011) applied single grain quartz OSL dating on four samples from the Althüttendorf sandur. This yields an average age of $20.1 \pm 1.6 \mathrm{ka}$ for the deposition of glaciofluvial sediments on the outwash plain which is interpreted to represent the main sandur accumulation phase associated with the Pomeranian IMP. Three samples from the Klosterbrücke outwash fan near Eberswalde give an average age of $19.4 \pm 2.4 \mathrm{ka}$, interpreted to represent the latest accumulation of glaciofluvial sediments associated with the presence of an ice margin at the Pomeranian IMP. In addition LÜTHGens, BöSE \& PREUSSER (2011) dated one sample from glaciofluvial sand incorporated within a succession of glaciolacustrine silt and clay accumulated within a depression formed by the melting of dead ice buried within the sediments of the Eberswalde IMV to $14.7 \pm 1.0 \mathrm{ka}$.

HeINE et al. (2009) dated the exposure of three erratic boulders from the Pomeranian terminal moraine (Fig. 3) by SED using ${ }^{10} \mathrm{Be}$. The observed scatter in ages, ranging from $17.7 \pm 0.9$ ka to $15.4 \pm 0.6$ (recalculated by Rinterkecht et al. 2010), is interpreted to indicate delayed stabilisation of the moraine surface after deglaciation. Following the argument of Reuther, Ivy-Ochs \& Heine (2006) they further conclude that melting of buried dead ice may have caused post-depositional rotation and delayed exhumation, resulting in younger exposure ages which do not reflect the initial timing of the deglaciation (HeINE et al. 2009). Despite this conclusion, these authors still argue that their ${ }^{10} \mathrm{Be}$ ages indicate a younger age of the Pomeranian moraine than previously reported for north-eastern Germany.

Based on the results from OSL dating of single aliquots of quartz, Brauer, Tempelhoff \& Murray (2005) ascribe the major part of the sediment succession exposed in the sand pit near Stolzenhagen $(\sim 15 \mathrm{~km}$ north of the terminal 
moraines of the Pomeranian IMP, Fig. 3) to the Saalian glaciation (with ages ranging from $158 \pm 9$ ka to $113 \pm 10$ ka for 10 samples). Only the uppermost sample from a sand layer exposed below a till ascribed to the Brandenburg phase of the Weichselian glaciation shows a significantly younger age of $32.5 \pm 1.8 \mathrm{ka}$. The authors interpret this age to represent the deposition of proglacial sediments in the course of the ice advance of the SIS to its maximum extent during the Brandenburg phase. However, they sound a note of caution concerning the interpretation of the single OSL age, because they can not rule out age overestimation caused by incomplete resetting prior to deposition based on their multigrain single aliquot SAR measurements (BRAUER, TEMPELHOFF \& MURRAY 2005).

RinTERKNECHT et al. (2010) dated samples of five glacigenic boulders from the Gerswalde terminal moraine, a recessional moraine approximately $30 \mathrm{~km}$ north of the terminal moraines of the Pomeranian phase (Fig.3). Four of the samples were consistently dated to $\sim 15 \mathrm{ka}$. One sample yielded a significantly lower age of $12.3 \pm 0.6 \mathrm{ka}$. The authors exclude this age as an outlier on a statistical basis (Chauvenet test), but do not provide a geomorphological explanation concerning possible causes for the delayed exposure of the boulder the sample was taken from. Based on the remaining four ages, which range from $14.8 \pm 0.8$ ka to $15.8 \pm 0.9$ ka, Rinterknecht et al. (2010) calculate an average exposure age of $15.2 \pm 0.5 \mathrm{ka}$ which they interpret to represent the depositional age of the Gerswalde terminal moraine. They also calculated an average exposure age of $16.4 \pm 0.7$ ka for the three boulders from the Pomeranian terminal moraine primarily dated by HeINE et al. (2009). Based on these ages these authors argue that the ice advance of the Pomeranian phase occurred later than previously estimated and may be attributed to a re-advance of the SIS margin during the initial warming phase subsequent to Heinrich event 1 (H1, $17 \mathrm{ka})$ in the North Atlantic region, but before the abrupt warming at the onset of the Bølling.

\section{Chronology of the main Weichselian IMPs in north- eastern Germany}

As a synthesis of the presented dating results we propose a new chronology for the main Weichselian IMPs in northeastern Germany (following the process based interpretation model for OSL and SED ages described in section 4). In the following also see Table 2 and Figure 4.

An advancing ice front of the SIS passed the Stolzenhagen area at $32.5 \pm 1.8 \mathrm{ka}$ (maximum age, BRAUER, TEMPELHOFF $\approx$ Murray 2005) and reached its maximum extent after $\sim 34$ ka (maximum age, Lüthgens, BöSE \& KRBETSCHEK 2010, LÜTHGENS et al. 2010), with first results from single grain quartz OSL indicating sandur accumulation associated with the Brandenburg IMP on the Beelitz outwash cone at 27.7 $\pm 4.0 \mathrm{ka}$ (LüthGENS 2011). Based on the available data, it remains unclear whether the SIS reached its maximum extent in north-eastern Germany in early MIS 2 or already in late MIS 3 (Figure 4A). Results of SED (HeINE et al. 2009) indicate a stabilisation of the landscape surface north of the Brandenburg IMP between $21.5 \pm 1.1 \mathrm{ka}$ and $18.9 \pm 0.9 \mathrm{ka}$, providing the minimum age of deglaciation for that area (Fig. 4B). Unfortunately, no numerical ages for glacigenic sediments associated with the Frankfurt phase are available yet. As already pointed out by BeHrmann (1949/50), the geological composition of the landforms points to older differences in elevation (occurrence of push morainic features), but the morphological forms indicate a weak disintegration of covering ice. It may therefore also be likely that the landforms associated with the Frankfurt phase represent a patchwork of landforms of different age rather than a synchronous IMP. Sandur formation associated with the Pomeranian IMP was dated to $20.1 \pm 1.6 \mathrm{ka}$ at Althüttendorf and 19.4 $\pm 2.4 \mathrm{ka}$ at Eberswalde (Klosterbrücke outwash fan) respectively (Figure 4C, Lüthgens, Böse \& Preusser 2011). Final stabilisation of the Pomeranian terminal moraine earliest at $17.7 \pm 0.9 \mathrm{ka}$ can be deduced from the SED ages of erratic boulders (HEINE et al. 2009, RinTERKNECHT et al. 2010). A period of boulder stabilisation at $15.8 \pm 0.9$ to $14.8 \pm 0.4 \mathrm{ka}$ in the area of the Gerswalde terminal moraine (RINTERKNECHT et al. 2010) provides a minimum age for deglaciation within that area and indicates further retreat of the SIS ice margin during the Gerswalde subphase (Figure 4D). This phase of boulder stabilisation is in good temporal agreement with the ages obtained for the deposition of periglacial cover sediments at $\sim 15 \mathrm{ka}$ on the Beelitz outwash cone (LüTHGENS et al. 2010) and on the outwash plains of the Pomeranian IMP in Mecklenburg-Vorpommern (KüSTER \& Preusser 2009). It also coincides with the meltout of buried dead ice within glaciofluvial sediments of the Eberswalde IMV documented by the accumulation of glaciofluvial sediments within a developing dead ice depression near Macherslust at $14.7 \pm 1.0 \mathrm{ka}$ (LÜTHGENS, BöSE \& Preusser 2011).

Based on these results, there is clear evidence for a twofold advance of the SIS in north-eastern Germany during the last glaciation (see Figure 4). The Brandenburg phase represents the maximum extent of the ice sheet sometime between 34-24 ka (LGM defined as maximum ice extent). The advance of the Pomeranian phase occurred at around $\sim 20 \mathrm{ka}$, which coincides with the LGM defined as the occurrence of the maximum global ice volume during the Weichselian glaciation as reconstructed from the marine isotope record (e.g. BARD 1999). This is in good agreement with the findings of JoHnsen, Olsen \& Murray (2010) who have given evidence for an interstadial from 25-20 ka in western Norway based on OSL and radiocarbon dating, dividing a formerly proposed single maximum ice advance into two stadials. Within the dynamic system of the SIS these effects were most likely not restricted to its western part, but would also have affected other sectors (JoHnSEN, Olsen \& Murray 2010). Taking a possible MIS 3 age of the Brandenburg phase into account, it may be correlated with the advance of the Klintholm ice stream in Denmark at about $32 \pm 4 \mathrm{ka}$ (based on OSL and calibrated radiocarbon ages of inter-till deposits) as reconstructed by HoumARKNiELSEN (2010). This author proposes that this Baltic ice advance took place under relatively mild interstadial conditions coinciding with Dansgaard-Oeschger events 7-5. It was possibly driven by effects of changes in regional glacier dynamics and external climatic forcing (primarily enhanced precipitation). Therefore the timing of this ice advance does not conflict with the occurrence of terrestrial organogenic sediments attributed to the Denekamp inter- 

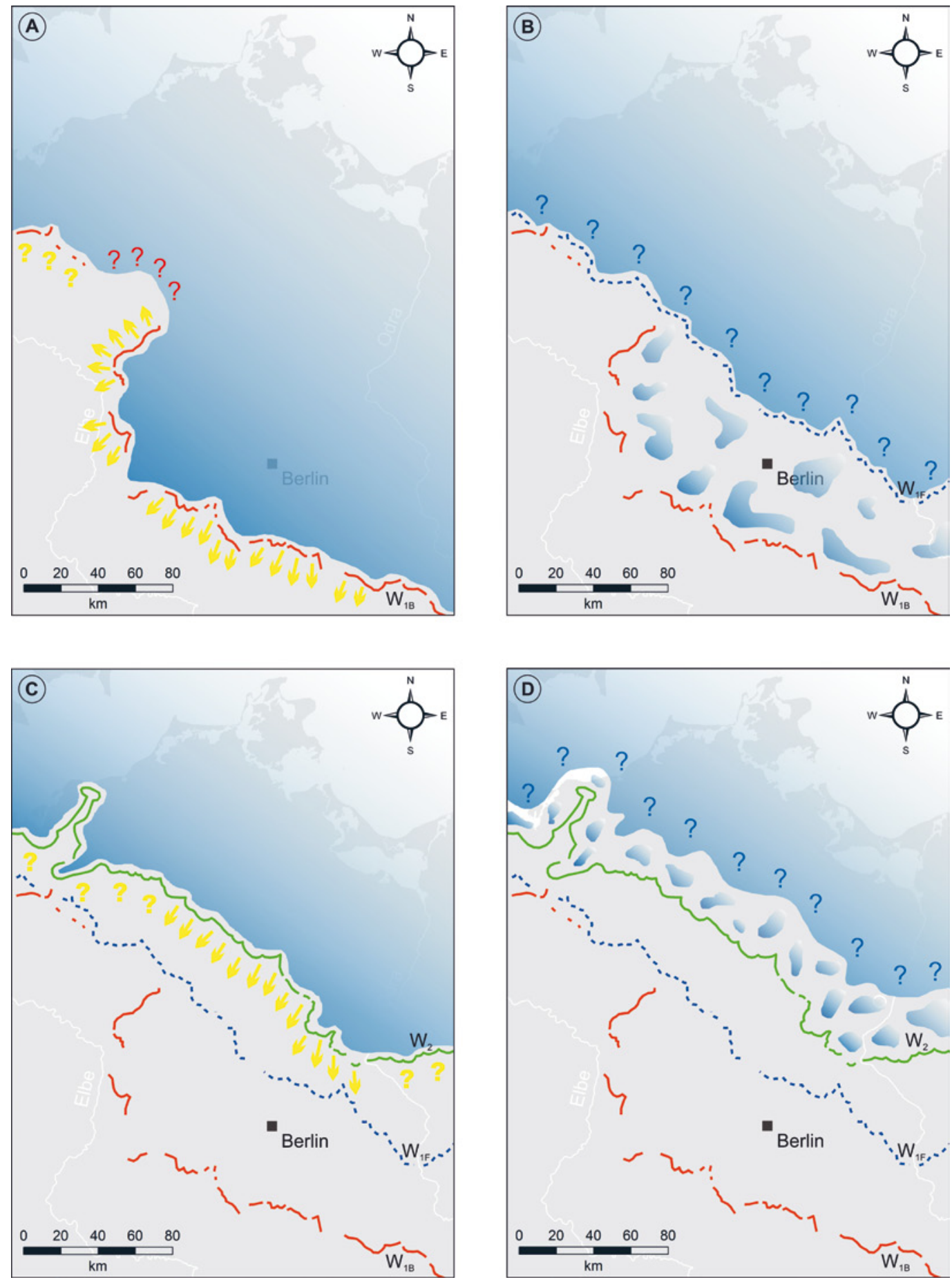

Fig. 4: For details concerning the base map we refer to the caption of figure 2. A) Extent of the SIS (blue shaded area) and position of the ice front at the Brandenburg IMP sometime between 34-24 ka implied by accumulation of glaciofluvial sediments on outwash plains (indicated by yellow arrows) dated by OSL (LÜTHGENS, BÖSE ひ KRBETSCHEK 2010, LÜTHGENS et al. 2010, LüTHGENS 2011). Unclear connections are indicated by question marks. B) Results from SED (Heine et al. 2009) provide a minimum age of $>23 \mathrm{ka}$ for the deglaciation (indicated by blue shaded patches) north of the Brandenburg IMP. However, it remains unclear how far the ice front had retreated at that time (possibly well north of the position indicated by blue question marks in the figure). C) Extent of the SIS and position of the ice front at the Pomeranian IMP at $\sim 20 \mathrm{ka}$ (based on results from OSL dating of sandur sediments, LüTHGENS, BÖSE, \& PREUSSER 2011). Correlations of the findings from Brandenburg with western Mecklenburg-Vorpommern and Schleswig-Holstein, as well as with Poland in the east remain unclear (indicated by yellow question marks). D) SED ages indicate initial deglaciation north of the Pomeranian IMP at least up to the Gerswalde IMP prior to $17 \mathrm{ka}$ (HEINE et al. 2009, RINTERKNECHT et al. 2010). The exact course of the SIS ice front at that time is still unclear. Abb. 4: Für Details hinsichtlich der Kartengrundlage verweisen wir auf die Bildunterschrift von Abbildung 2. A) Ausdehnung des SIS (blau schattierter Bereich) und Lage des Eisrandes zu einem Zeitpunkt zwischen 34-24 ka, basierend auf OSL Datierungen (LÜTHGENS, BÖSE ひ KRBETSCHEK 2010, LÜTHGENS et al. 2010, LÜTHGENS 2011) von Sandersedimenten. Unklare Verbindungen werden durch Fragezeichen markiert. B) Ergebnisse von Expositionsdatierungen (HEINE et al. 2009) liefern ein Minimalalter für das Niedertauen und die Eisfreiwerdung (Gebiet mit blau schattierten Flecken) nördlich der Brandenburger Eisrandlage von $>23 \mathrm{ka}$. Es bleibt jedoch unklar wie weit nördlich das Niedertauen zu diesem Zeitpunkt fortgeschritten war (möglicherweise deutlich weiter als auf der Abbildung durch Fragezeichen markiert). C) Ausdehnung des SIS und Lage des Eisrandes an der Pommerschen Eisrandlage um ca. $20 \mathrm{ka}$ (basierend auf Ergebnissen von OSL Datierungen von Sandersedimenten, LÜTHGENS, BÖSE \& PREUSSER 2011). Die Korrelation der in Brandenburg gewonnenen Erkenntnisse mit dem westlichen Mecklenburg-Vorpommern und Schleswig-Holstein, sowie nach Osten hin mit Polen muss weiterhin als unklar angesehen werden (markiert durch gelbe Fragezeichen). D) Expositionsalter deuten auf eine Eisfreiwerdung nördlich der Pommerschen Eisrandlage mindestens bis zur Gerswalder Eisrandlage bereits vor $17 \mathrm{ka}$ (HEINE et al. 2009, RINTERKNECHT et al. 2010). Der genaue Verlauf des Eisrandes ist jedoch derzeit noch unklar. 


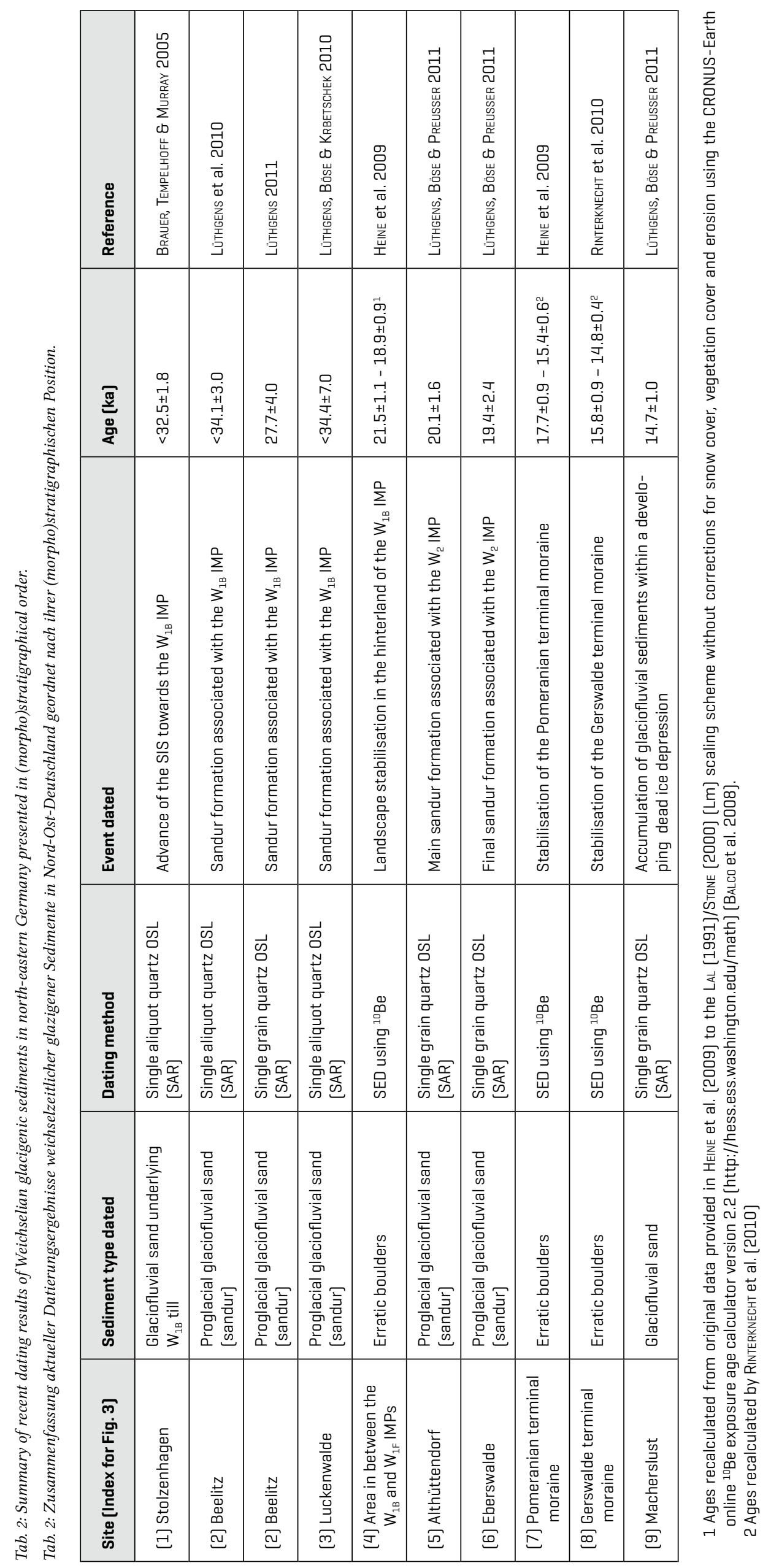


stadial ( 30 ka (cal.), LiTT et al. 2007) based on palynological findings and radiocarbon dating. However, we advise caution concerning the interpretation of the first few numerical ages available from the Brandenburg phase. Although different scenarios may seem plausible (including an MIS 3 advance), additional investigations are necessary to further clarify the age of the $\mathrm{W}_{1 \mathrm{~B}}$ ice advance.

MARKS (2010) discussed the concept of an MIS 3 ice advance for Poland based on his reinterpretation of ${ }^{36} \mathrm{Cl}$ SED ages of DzIERZEK \& ZREDA (2007). Inferred from results of cosmogenic dating of erratic boulders and landscape surfaces using ${ }^{36} \mathrm{Cl}$, Dzierzek \& ZREDA (2007) provide an age of 27-28 ka for the initial deglaciation after the first ice advance in north-eastern Poland. However, MARKs (2010) provides a maximum age of $24 \mathrm{ka}$ for the Lezno phase in Poland which is usually correlated with the Brandenburg phase in Germany. This age estimate is based on a number of radiocarbon ages clustering around $25 \mathrm{ka}$ (cal.) derived from peat underlying the glacigenic sediments in the area of Konin and from organic silts in the Pomeranian bay (Baltic Sea). These ages may correlate well with the interstadial proposed by JoHnsen, Olsen \& Murray (2010). However, they impede a direct correlation of the chronology for north-eastern Germany with that of Poland. The determination of the yet unknown chronostratigraphical position of the Frankfurt phase in Germany may help to solve this issue.

Due to the time transgressive nature of morphostratigraphically defined IMPs (MARKs 2002, LüTHGENS \& BöSE 2010), we refrain from any correlations with available SED data for the LGM from Lithuania and Belarus (Rinterknecht et al. 2006a, 2007, 2008). The age of the Pomeranian phase in Poland has mainly been based on the results from SED using ${ }^{10} \mathrm{Be}$ (RINTERKNECHT et al. 2005, 2006a). Lüthgens, Böse \& Preusser (2011) provide a detailed discussion on the reassessment of these ages with respect to the process-based interpretation model described above. For this review we will therefore only focus on the SED ages obtained from the Pomeranian phase in western Poland. Excluding low outliers exposed during the Holocene, eight SED ages are available ranging from $18.0 \pm 1.3 \mathrm{ka}$ to $10.8 \pm 0.8$ ka with ages clustering around $\sim 15 \mathrm{ka}$. Given their widespread dispersion in western Poland (distances of $>100 \mathrm{~km}$ between individual boulders, cf. MARKs 2010: Fig. 7) their geochronological significance for the age of the Pomeranian moraine seems questionable. However, the sample from the boulder situated closest to the Pomeranian IMP also yields the oldest age of $18.0 \pm 1.3 \mathrm{ka}$, which is in perfect agreement with the phase of boulder stabilisation of the Pomeranian terminal moraine in north-eastern Germany based on the SED ages of HeINE et al. (2009).

In addition, there is now geochronometrical evidence (Brauer, Tempelhoff \& Murray 2005, Lüthgens, Böse \& KRBETSCHEK 2010) that the ice advance to the Brandenburg IMP only reshaped a relief initially generated by the Saalian glaciation. LüthGENS, BöSE \& KRBETSCHEK (2010) further suggest that transformation of the relief was mainly linked to meltwater processes, implying a fast-paced and short-lived ice advance. In contrast, the ice advance during the Pomeranian phase shaped the most prominent ice marginal features (terminal moraines and outwash plains) in north-eastern Germany. LüTHGENS (2011) points out that these different characteristics in ice dynamics are additionally deducible from the different luminescence characteristics observed for glaciofluvial sediments associated with both phases. Although taken from identical depositional environments, all samples from the Brandenburg phase showed incomplete resetting of the OSL signal, whereas the majority of samples from the Pomeranian IMP did not suffer from that problem. LÜTHGENS (2011) suggests that this may indicate a very limited reworking of the glaciofluvial sediments on the elevated outwash cones of the Brandenburg IMP, with meltwater flow quickly shifting to the incised fluvioglacial channel system.

Finally, we would like to point out that first OSL ages for the deposition of periglacial cover-sediments may point toward an activity phase at $\sim 15 \mathrm{ka}$ (Beelitz outwash cone - Lüthgens et al. 2010, Pomeranian outwash plain Küster \& Preusser 2009). This coincides with age clusters observed from SED datasets indicating increased exposure of glacigenic boulders at that time (Gerswalde subphase RinterkneCht et al. 2010, areas ascribed to the Pomeranian phase in north-eastern Germany, Poland, Lithuania, Latvia, Belarus - Heine et al. 2009, Rinterknecht et al. 2005, 2006a, 2007, 2008). Lüthgens, BöSE \& Preusser (2011) recently verified the statistical significance of that age cluster for a dataset containing all SED ages available from the Pomeranian phase. As proposed by Küster o Preusser (2009) this activity phase at $\sim 15$ ka correlates well with the formation of the Beuningen gravel bed (BGB) which serves as an important marker horizon in the late Weichselian coversand stratigraphy of Western Europe (VANDEnBerghe 1985, KASSE 2002). KASSE at al. (2007) provide bracketing ages of $17.2 \pm 1.2 \mathrm{ka}$ and $15.3 \pm 1.0 \mathrm{ka}$ for the formation of the BGB in the southern Netherlands based on results from OSL dating of quartz and propose a correlation with Heinrich event $\mathrm{H} 1$. However, the implied correlation of the formation of the BGB, the formation of periglacial cover-sediments, and the enhanced exposure of erratic boulders needs further investigation in order to be reliably validated. The age of $14.7 \pm 1.0 \mathrm{ka}$ from the Macherslust section (Lüthgens, Böse \& Preusser 2011) may serve as a first geochronological marker for the meltout of buried dead ice in north-eastern Germany at the onset of the Meiendorf and the subsequent Bølling warming period, but the question when dead ice finally melted remains to be specified.

Within this review we summarised the newly available numerical ages for Weichselian glacigenic sediments from north-eastern Germany and propose a new chronology for the main Weichselian ice marginal positions. However, as already pointed out by LüTHGENS (2011) a range of open questions remains to be answered. Firstly, the exact timing of the Brandenburg IMP needs to be specified in order to finally give evidence for its geochronological assignment to either MIS 2 or MIS 3. Secondly, the geochronological position of the Frankfurt IMP and the question of its morphostratigraphical integrity remain to be clarified. Finally, geochronometrical data for recessional IMPs, especially north of the Pomeranian IMP, need to be obtained in order to be able to fully reconstruct the deglaciation pattern of the Weichselian SIS in north-eastern Germany from its 
maximum extent at the Brandenburg IMP to its northward retreat beyond the recent shoreline of the Baltic Sea.

\section{Acknowledgements}

We would like to thank Robert Hebenstreit for many fruitful and inspiring discussions concerning the interpretation of cosmogenic exposure ages of erratic boulders in the context of the glacial landscape in north-eastern Germany. We would also like to thank two reviewers for their valuable comments on an earlier version of the manuscript which greatly helped to improve the outcome of this study.

\section{References}

Balco, G., Stone, J.O., Lifton, N.A. \& Dunai, T.J. (2008): A complete and easily accessible means of calculating surface exposure ages or erosion rates from ${ }^{10} \mathrm{Be}$ and ${ }^{26} \mathrm{Al}$ measurements. - Quaternary Geochronology, 3: 174-195.

BARD, E. (1999): Ice Age Temperatures and Geochemistry. - Science, 284: 1133-1134.

BAILEY, R.M. \& ARNold, L.J. (2006): Statistical modelling of single grain quartz De distributions and an assessment of procedures for estimating burial dose. - Quaternary Science Reviews, 25: 2475-2502.

Behrmann, W. (1949/50): Die Umgebung Berlins nach morphologischen Formengruppen betrachtet. - Die Erde, 1: 93-122.

BösE, M. (1994): Ice margins and deglaciation in the Berlin area between Brandenburg and Frankfurt end moraines - a review. - Zeitschrift für Geomorphologie N.F., Suppl. 95: 1-6.

Böse, M. (2005): The Last Glaciation and Geomorphology. - In: Koster, E.A. (ed.): The Physical geography of Western Europe: 61-74; Oxford University Press.

Bøtter-Jensen, L., McKeever, S.W.S. \& Wintle, A.G. (2003): Optically Stimulated Luminescence Dosimetry. - Elsevier, Amsterdam.

Brauer, A., Tempelhoff, K. \& Murray, A. (2005): OSL Dating of FineGrained Sand Deposits and its Implications for Glacial Stratigraphy and Landscape Evolution: Research Results from Stolzenhagen, Northeastern Brandenburg. - Die Erde, 136: 15-35.

Brose, F. (1995): Erscheinungen des weichselzeitlichen Eisrückzuges in Ostbrandenburg. - Brandenburgische Geowissenschaftliche Beiträge, 1995 (1): 3-11.

CEPEK, A.G. (1965): Die Stratigraphie der pleistozänen Ablagerungen im Norddeutschen Tiefland. - In: Gellert, J.F. (ed.): Die Weichsel-Eiszeit im Gebiet der DDR: 45-65

Duller, G.A.T. (2008): Single-grain optical dating of Quaternary sediments: why aliquot size matters in luminescence dating. - Boreas, 37: 589-612.

DzIERZEK, J. \& ZREDA, J. (2007): Timing and style of deglaciation of northeastern Poland from cosmogenic ${ }^{36} \mathrm{Cl}$ dating of glacial and glaciofluvial deposits. - Geological Quarterly, 51-2: 203-216.

Ehlers, J. \& GibBard, P.L. (eds.) (2004): Quaternary Glaciations - Extent And Chronology - Part I: Europe. - Elsevier; Amsterdam.

Everest, J. \& BRADWELL, T. (2003): Buried glacier ice in southern Iceland and its wider significance. - Geomorphology, 52: 347-358.

Fuchs, M. \& OWEN, L.A. (2008): Luminescence dating of glacial and associated sediments: review, recommendations and future directions. Boreas, 37: 636-659.

Galbraith, R.F., Roberts, R.G., Laslett, G.M., Yoshida, H. \& Olley, J.M. (1999): Optical dating of single and multiple grains of Quartz from Jinmium rock shelter, northern Australia: Part I, experimental design and statistical models. - Archaeometry, 41: 339-364

Gosse, J.C. \& Phillips, F.M. (2001): Terrestrial in situ cosmogenic nuclides: Theory and application. - Quaternary Science Reviews, 20: 1475-1560.

Heine, K., Reuther, A.U., Thieke, H.U., Schulz, R., SchlaAk, N. \& KubIK, P.W. (2009): Timing of Weichselian ice marginal positions in Brandenburg (northeastern Germany) using cosmogenic in situ 10Be. - Zeitschrift für Geomorphologie N.F., 53 (4): 433-454.

Houmark-Nielsen, M., Björck, S. \& Wohlfarth, B. (2006): 'Cosmogenic $10 \mathrm{Be}$ ages on the Pomeranian Moraine, Poland': Comments. - Boreas, 35: $600-604$

Houmark-Nielsen, M. (2010): Extent, age and dynamics of Marine Isotope Stage 3 glaciations in the southwestern Baltic Basin. - Boreas, 39: 343-359.
Ivy-Ochs, S. \& Kober, F. (2008): Surface exposure dating with cosmogenic nuclides. - Eiszeitalter und Gegenwart, 57 (1/2): 179-209.

Jarvis, A., Reuter, H.I., Nelson, A. \& Guevara, E. (2006): Hole-filled seamless SRTM data V3. - International Centre for Tropical Agriculture (CIAT); available from http://srtm.csi.cgiar.org.

Juschus, O. (2001): Das Jungmoränenland südlich von Berlin - Untersuchungen zur jungquartären Landschaftsentwicklung zwischen Unterspreewald und Nuthe, (dissertation at the Humboldt Universität zu Berlin). http://edoc.hu-berlin.de/dissertationen/juschus-olaf-2001-05-04/ PDF/Juschus.pdf. 251 p; Berlin.

Johnsen, F.J., Olsen, L. \& Murray, A.S. (2010) in press: OSL ages in central Norway support a MIS 2 interstadial (25-20 ka) and a dynamic Scandinavian ice sheet. - Quaternary Science Reviews: DOI: $10.1016 /$ j.quascirev.2010.10.007

KASSE, C. (2002): Sandy aeolian deposits and environments and their relation to climate during the Last Glacial Maximum and Lateglacial in northwest and central Europe. - Progress in Physical Geography, 26: 507-532.

Kasse, C., Vandenberghe, J., De Corte, F. \& Haute van den, P. (2007): Late Weichselian fluvio-aeolian sands and coversands of the type locality Grubbenvorst (southern Netherlands): sedimentary environments, climate record and age. - Journal of Quaternary Science, 22/7: 695-708.

KeilHack, K. (1909): Begleitworte zur Karte der Endmoränen und Urstromtäler Norddeutschlands. - Jahrbuch der Königlich Preussischen geologischen Landesanstalt und Bergakademie zu Berlin, 30 (1) 507-510.

KLIEWE, H. \& JAHNKE, W. (1972): Verlauf und System der Marginalzonender letzten Vereisung auf dem Territorium der DDR. - Wissenschaftliche Zeitschrift der Erns-Moritz-Arndt-Universität Greifswald - Mathematisch-Naturwissenschaftliche Reihe, 21: 31-37.

KozARSKI, S. (1992): Eine auf der Radiokarbonmethode basierende Abschätzung der Rückzugschronologie des letzten Inlandeises in Nordpolen. In: Billwitz, K., JäGER, K.D. \& JANKe, W. (eds.): Jungquartäre Landschaftsräume: 16-22; Berlin.

KozArski, S. (1995): Deglacjacja pólnocno-zachodniej Polski: womki i trasformacja geosystema ( 20 ka-10 ka). - Documentacja Geograficzna 82.

Küster, M. ¿ Preusser, F. (2009): Late Glacial and Holocene aeolian sands and soil formation from the Pomeranian outwash plain (Mecklenburg, NE-Germany). - E\&G Quaternary Science Journal, 58: 156-163.

LAL, D. (1991): Cosmic ray labeling of erosion surfaces: in situ nuclide production rates and erosion models. - Earth and Planetary Science Letters, 104: 424-439.

LIAN, O. B. \& Roberts, R. G. (2006): Dating the Quaternary: progress in luminescence dating of sediments. - Quaternary Science Reviews, 25: $2449-2468$

LibBY, W.F. (1952): Radiocarbon Dating. - University of Chicago Press; Chicago.

LiedtKe, H. (1975): Die Nordischen Vereisungen in Mitteleuropa. - Forschungen zur deutschen Landeskunde, 204; Bonn.

LiedtKe, H. (1981): Die Nordischen Vereisungen in Mitteleuropa. - Forschungen zur deutschen Landeskunde, 204 (2nd edition); Trier.

LiedTKe, H. (1996): Die eiszeitliche Gestaltung des Oderbruchs. - Heidelberger Geographische Arbeiten, 104: 327-351.

LiEDTKE, H. (2001): Das nordöstliche Brandenburg während der Weichseleiszeit. - In: Bussemer, S. (ed.): Das Erbe der Eiszeit: 119-133; Langenweißbach.

Lippstreu, L. (1995): Brandenburg. - In: BendA, L. (ed.): Das Quartär Deutschlands: 116-147; Berlin.

Litt, T., Behre, K.-E., Meyer, K.-D., Stephan, H.-J. \& WANSA, S. (2007): Stratigraphische Begriffe für das Quartär des norddeutschen Vereisungsgebietes. - In: LITT, T. (ed.): Stratigraphie von Deutschland Quartär. - E\&G Quaternary Science Journal, 56: 7-65.

LüTHGENS, C. (2011): The age of Weichselian main ice marginal positions in north-eastern Germany inferred from Optically Stimulated Luminescence (OSL) dating. - PhD thesis, Freie Universität Berlin, available from: http://www.diss.fu-berlin.de/diss/receive/FUDISS_thesis_000000022882

LÜTHGENS, C. \& Böse, M. (2010) in press: From morphostratigraphy to geochronology - on the dating of ice marginal positions. - Quaternary Science Reviews, DOI: 10.1016/j.quascirev.2010.10.009

Lüthgens, C., Böse, M. \& Krbetschek, M.R. (2010): On the age of the young morainic morphology in the area ascribed to the maximum extent of the Weichselian glaciation in north-eastern Germany. - Quaternary International, 222: 72-79. 
Lüthgens, C., Böse, M. \& Preusser, F. (in press): Age of the Pomeranian ice marginal position in north-eastern Germany determined by Optically Stimulated Luminescence (OSL) dating of glaciofluvial sediments. - Boreas, DOI: 10.1111/j.1502-3885.2011.00211.x

Lüthgens, C., KrbetscheK, M.R., Böse, M. \& Fuchs, M.C. (2010): Optically Stimulated Luminescence Dating of fluvioglacial (sandur) sediments from north-eastern Germany. - Quaternary Geochronology, 5: 237-243.

LüTtig, G. (2005): Geschiebezählungen im westlichen Mecklenburg. - Archiv für Geschiebekunde, 4: 569-600.

Marks, L. (2002): Last Glacial Maximum in Poland. - Quaternary Science Reviews, 21: 103-110.

Marks, L. (2010) in press: Timing of the Late Vistulian (Weichselian) glacial phases in Poland. - Quaternary Science Reviews, DOI:10.1016/j. quascirev.2010.08.008

Murray, A.S. \& Wintle, A.G. (2000): Luminescence dating of Quartz using an improved single aliquot regenerative dose protocol. - Radiation Measurements, 32: 57-73.

Murray, A.S. \& Wintle, A.G. (2003): The single aliquot regenerative dose protocol: potential for improvements in reliability. - Radiation Measurements, 37: 377-381.

Penck, A. (1879): Die Geschiebeformation Norddeutschlands. - Zeitschrift der Deutschen Geologischen Gesellschaft, 31: 117-203.

Penck, A. (1882): Die Vergletscherung der deutschen Alpen: ihre Ursachen, periodische Wiederkehr und ihr Einfluss auf die Bodengestaltung. - Barth; Leipzig.

Preusser, F., Degering, D., Fuchs, M., Hilgers, A., Kadereit, A., Klasen N., KrbetscheK, M., Richter, D. \& Spencer, J.Q.G. (2008): Luminescence dating: basics, methods and applications. - E\&G Quaternary Science Journal, 57: 95-149.

Reuther, A.U., Ivy-Ochs, S. \& Heine, K. (2006): Application of surface exposure dating in glacial geomorphology and the interpretation of moraine ages. - Zeitschrift für Geomorphologie N.F., 142: 335-359.

Rinterknecht, V.R., Bitinas, A., Clark, P.U., Raisbeck, G.M., Yiou, F. \& Brook, E.J. (2008): Timing of the last deglaciation in Lithuania. Boreas, 37: 426-433.

Rinterknecht, V.R., Braucher, R., Böse, M., Bourlès, D. \& Mercier, J.-L. (2010) in press: Late Quaternary ice sheet extents in northeastern Germany inferred from surface exposure dating. - Quaternary Science Reviews, DOI: 10.1016/j.quascirev.2010.07.026

Rinterknecht, V.R., Clark, P.U., Raisbeck, G.M., Yiou, F., Bitinas, A., Brook, E.J., Marks, L., Zelčs, V., Lunkka, J.-P., Pavlovskaya, I.E.,
Piotrowski, J.A. \& Raukas, A. (2006a): The Last Deglaciation of the Southeastern Sector of the Scandinavian Ice Sheet. - Science, 311: $1449-1452$

Rinterknecht, V.R., Marks, L., Piotrowski, J., Raisbeck, G.M., Yiou, F., Brook, E.J. \& Clark, P.U. (2005): Cosmogenic ${ }^{10} \mathrm{Be}$ ages on the Pomeranian Moraine, Poland. - Boreas, 34: 186-191.

Rinterknecht, V.R., Marks, L., Piotrowski, J., Raisbeck, G. M., Yiou, F, Brook, E.J. \& Clark, P.U. (2006b): 'Cosmogenic ${ }^{10} \mathrm{Be}$ ages on the Pomeranian Moraine, Poland': Reply to comments. - Boreas, 35: 605-606.

Rinterknecht, V.R., Pavlovskaya, I.E., Clark, P.U., Raisbeck, G. M., Yiou, F. \& Brook, E.J. (2007): Timing of the last deglaciation in Belarus. - Boreas, 36: 307-313.

Stone, J.O. (2000): Air pressure and cosmogenic isotope production. Journal of Geophysical Research, 105: 753-23, 759.

Stuiver, M., Reimer, P. J., Bard, E., Beck, J. W., Burr, G. S., Hughen, K. A., Kromer, B., McCormac, G., Der Plicht, V. J., \& Spurk, M. (1998): INTCAL98 radiocarbon age calibration 24000-0 cal BP (1950). - Radiocarbon, 40: 1041-1083.

Terberger, T., Klerk, P. De, Helbig, H., Kaiser, K. \& Kühn, P. (2004) Late Weichselian landscape development and human settlement in Mecklenburg-Vorpommern (NE Germany). - Eiszeitalter und Gegenwart, 54: 138-175.

Thrasher, I.M., Mauz, B., Chiverrell, R.C. \& Lang, A. (2009): Luminescence dating of glaciofluvial deposits: A review. - Earth-Science Reviews, 97: 133-146.

ToRell, O. (1875): Ueber das norddeutsche Diluvium. In: Beyrich, V., Rammelsberg \& W., Weiss, O.: Verhandlungen der Gesellschaft - Protokoll der November-Sitzung. - Zeitschrift der Deutschen Geologischen Gesellschaft, 27: 958-962.

VAndenberghe, J. (1985): Paleoenvironment and stratigraphy during the Last Glacial in the Belgian-Dutch Border Region. - Quaternary Research, 24: 23-38.

Wintle, A.G. (2008a): Fifty years of luminescence dating. - Archaeometry, 50: 276-312.

WintLe, A.G. (2008b): Luminescence dating. Where it has been and where it is going. - Boreas, 37: 471-482

Wintle, A.G. \& Murray, A.S. (2006): A review of quartz optically stimulated luminescence characteristics and their relevance in single-aliquot regeneration dating protocols. - Radiation Measurements, 41: 369-391.

Woldstedt, P. (1925): Die großen Endmoränenzüge Norddeutschlands. - Zeitschrift der Deutschen Geologischen Gesellschaft, 77: 172-184. 